\title{
Ideology and Media Framing: Stigmatisation of LGBT in Media Coverage in Indonesia
}

\author{
HAMDANI M. SYAM \\ NUR ANISAH \\ RAHMAT SALEH \\ MURTI ALI LINGGA \\ Universitas Syiah Kuala, Indonesia
}

\begin{abstract}
This essay analyzes how the ideology that is owned by the media influences the media's framing in reporting a reality. The framing dimension will always be related to the selection of issues, emphases, and projection on certain aspects of the issue. For this reason, this study will present the media cases of Republika.co.id and Tempo.co in informing LGBT reality. So, the reality of LGBT conveyed by Republika.co.id and Tempo.co cannot be seen separately, because it will be related to the interests that these two media outlets want to serve by reporting the reality. The analysis demonstrates that the reporting of Republika.co.id and Tempo.co on LGBT is influenced by each outlet's ideology. Republika.co.id, which embraces the ideology of nationalism and Islam, tends to report the rejection of LGBT presence in Indonesia. Republika.co.id provides a negative stigma against LGBT issues. It is considered that LGBT is a serious threat to the nation and state because behaviour is deemed not following religion, generally applicable social norms, and the laws of Indonesia. Tempo.co does not see LGBT as a serious problem for the Indonesian people. Tempo.co considers the behaviour and activities of LGBT people to be normal, which is part of human rights that must be respected by the Indonesian people.
\end{abstract}

Keywords: Ideology, framing, LGBT, media coverage, Indonesia.

\section{INTRODUCTION}

In Indonesia, the majority of the population is Muslim. Islam forbids humans to have lesbian, gay, bisexual, and transgender (LGBT) sex. Indonesian state legislation recognises only two sexes, male and female. The issue of LGBT is so strong and has been in the spotlight of the mass media in Indonesia in the last five years. In mid-2015, Indonesians were shocked by the issue of gay marriage between Tiko Mulya, an Indonesian citizen, with Joe Trully, a US citizen in Bali (Tempo.co, 2015). A similar event happened again in Boyolali, Central Java, namely the marriage between Airin Carla and Dumani (Bramantyo, 2015). Their wedding photos uploaded to Facebook made this event a hot news item in the mass media. News about LGBT re-emerged in the Indonesian mass media in early 2016, when there was a clamour for the Support Group and the Resource Center (SGRC) on Sexuality Studies at Universitas Indonesia.

The events regarding LGBT have been reported by the Indonesian mass media from a certain perspective. Some media oppose LGBT presence in this country, and some media accept it. At that time, the Indonesian people were presented with LGBT news in printed, electronic, and online forms. This is proof that Indonesian media still thinks that LGBT presence in Indonesia is important enough to be reported. Each media institution has a different perspective in reporting reality, including reporting on the reality of LGBT. 
According to Entman (2007), Engel (2013), and Scheufele with Tewksbury (2006), the media are not a value-free channel, but they are complete with views, biases, and partiality. The mass media act as a construction medium for the real facts that exist in the field. Mass media have an important role in spreading ideology and as an instrument in the formation of public opinion. Based on that, Engel (2013) said that news is not a reflection and a real reality, but has been constructed from a certain reality Engel (2013) states that news is not a reflection and real reality, but is constructed from certain realities by journalists. According to Entman (2007), Bovitz et al. (2002), Cotterrell (1999), Deuze (2004), and lyengar with Hahn (2009), the reporting of reality will always be related to the characteristics, interests, and ideology of the media. Although the media generally function as a watchdog, the function cannot be executed properly. The real function of the media reveals that the media have an interest in the reality reported. This interest will influence media framing in the news.

This study examines ideological concepts and the framing of media about LGBT reporting in the mass media in Indonesia. This research focuses on two mass media outlets, namely Republika.co.id and Tempo.co. Research on these two media outlets related to the reporting of LGBT issues is interesting to study because these two media outlets have different backgrounds and ideologies. Republika.co.id as an Islamic-based, nationalistic medium (Wahid \& Yakut, 2018). Tempo.co has an ideology of freedom, diversity, and humanity (Fathurokhmah, 2015). Will this difference give its stigma regarding LGBT issues? This research is present is to answer that problem.

\section{LITERATURE REVIEW}

How Media Cover the News of LGBT in Other Countries

Research conducted by Pan et al. (2010) explained gay marriage which is described in the news coverage of The New York Times and Chicago Tribune in The United States. The finding described The New York Times which is liberal-oriented tend to show the journalists' personal opinion about gay marriage. The New York Times stance supports the Massachusetts Supreme Court's decision that has legitimized gay marriage in the United States. It is different from the Chicago Tribune which is conservative, has framed the news about gay marriage based on The United States traditional values and family institutions. Chicago Tribune attempts to oppose the Massachusetts Supreme Court's decision that has legitimized gay marriage in the United States. Chicago Tribune emphasizes the principle of individual freedom, the role of the states is not needed to obstruct it.

The next research is conducted by Njoroge (2020), who studied the framing of homosexuality on mass media in Kenya. It employed content analysis on the news reporting of the national daily newspaper, found the result that mass media in Kenya are against homosexuality. The news reporting which go against homosexuality is influenced by values owned by journalists and media practitioners in Kenya. They are parts of society that oppose homosexuality. Homosexuality is assumed as a sin, unreasonable and unfaithful. The journalists have strong faith in homosexuality which is not African and not part of African culture.

Another research did by Adegbola (2019) on the homosexuality issue in Nigerian newspapers. The research described modality owned by journalists has influenced news reporting about homosexuality in Nigerian mass media. Journalists in Nigeria oppose homosexuality by inciting readers to rise and oppose radically any culture which may destroy African culture. Through modality owned by journalists had debated about 
homosexuality based on culture, religion, law and health in the Nigerian context. The journalists' point of view presented in news reporting thus shows that homosexuality becomes a controversial issue in Nigerian society and politics.

Based on findings of past researches, it summed up that values owned by a journalist and media ideology can influence the form of news reporting regarding LGBT. These past research findings are relevant to the research findings presented by Fathurokhmah (2015), Shoemaker and Reese (1996), Snow (2004), Snow and Byrd (2007), Scheufele and Tewksbury (2006), with Wahid and Yakut (2018), which suggested that values owned by the journalist as well as media ideology can influence news reporting on certain issues, including LGBT issue.

\section{Framing Media Concept}

The concept of framing is widely used by many communication scholars including Wahid \& Yakut (2018), Engel (2013), Chong and Druckman (2007), Entman (1993, 2007), Shoemaker et al. (2009), Kee et al. (2012), Fong (2016), Hassan et al. (2017), Snow (2004), Scheufele and Tewksbury (2006), Hamdy and Gomaa (2012), De Vreese (2005), Arandas et al. (2019) and many others. Framing has been used by these scholars to see the selection process and highlight certain aspects of the media's interpretation of reality. When a fact is reported in the mass media, the discussion often arises whether the facts are reported as they are, or are facts developed to a support specific purpose. Therefore, framing is an attempt to find out how journalists use a perspective when selecting issues and writing news. According to Shoemaker et al. (2009), the perspective of journalists determines the facts of what is taken, highlighted, eliminated, how it is written, and what to bring to where the news is. The standard that is always used in media framing is how to write news so that the news has its interests.

De Vreese (2005), Scheufele (1999) and Fong et al. (2016) state that the phenomenon that appears in a news report has passed a complicated and long process. Talking about news as a fact can be analogous not to a mirror that displays objects as they are, but to a window that allows people to view the world within the frame of the window. News coverage in the mass media depends on the perspective of journalists who have subjectivity (Entman, 1993, 2007). According to Shoemaker et al. (2009), journalistic subjectivity is affected by the internal situation of media organisations and external forces. Therefore, framing provides the key to how events are understood by the media and interpreted in the form of news. The media sees events from a particular perspective, and so the reality seen by the public is the reality that has been formed by the media frame.

Framing is generally characterised by highlighting certain aspects of reality. News is either consciously or not consciously directed at certain aspects. As a result, other aspects do not get adequate attention in media coverage. The strength of framing is its ability to mass mobilise. It is widely used by journalists in reporting to mobilise the community. The strategy is how the audience has the same view on an issue. It is often characterised by creating common problems, common enemies, and shared heroes. All that requires a frame of how issues are packaged, how events are understood, and how events are interpreted and defined. The strength of other framing is that it can lead audiences to certain memories. Individuals know events in the community from media coverage. Audiences get information from the media about the reality around them. Therefore, how the media frames certain realities influences how individuals interpret these events (Scheufele, 1999). 


\section{The Importance of Ideology in News}

The media are actually in the midst of a social reality that is full of various complex and diverse interests. Studies by Shoemaker and Reese (1996), Deuze (2004), Snow and Byrd (2007), Entman (1993), Pasha (1993), Hackett (1984), Bennett (2005), Snow (2004) and Arandas et al. (2019) state that the mass media are not free of value, but they are connected with various interests. The media have an interest in the country, the community, the interests of the capital owners, the interests of the sustainability of the work for the employees, and the interests of media ideology itself. This causes news that highlights certain realities and ignores or eliminates other realities obtained by journalists from different sources when in the field. According to Shoemaker and Reese (1996, p. 221), Reese (2001), and Snow (2004), that ideology is defined as a framework of thinking or reference framework used by the media to see reality to be used as news material.

According to Scheufele (1999), Snow and Byrd (2007), Atton (2009), and Arandas et al. (2019), the interests of the ideology of media will always be related to the concept of framing. The media play a role in defining how reality should be understood, how reality is explained in a particular way to the public. News is the result of social construction that always involves certain views, symbols, and values. How reality is made into news depends on how the facts are understood and interpreted. If the meaning process always uses symbols and elements of certain values, the news will follow the symbols and values. Then, the same event can produce different news because of the different ways of seeing in terms of framing the news.

Media ideology is a very serious concern by the media in the news. When there is a reality that is appropriate or contrary to its ideology, the media will package that reality very carefully so that the reality conveyed is not only accepted by the reader but also in line with its ideological interests. The media see events with certain perspectives and views because, in the process of seeing the event, the media uses a certain point. The point and position of view describe how events are explained in a particular frame of mind. According to Shoemaker and Reese (1996, p. 221) with Oliver and Johnston (2005), media ideology is attached to the institution itself whose direction is determined by the structure of their respective institutions. Ideology in the media cannot be separated from the elements of value and importance. Although ideology is abstract, it can influence the formation of news. A text reported by the media is never separated from ideology and will tend to manipulate the reader in favour of its ideology (Wahid \& Yakut, 2018).

\section{Ideology of Republika.co.id and Tempo.co}

The ideology of a medium can be seen from its vision and mission, its founding background, its purpose, what it wants to fight for, and what influences it in determining the content of the news (Akhavan-Majid \& Ramaprasad, 1998). Thus, the media ideologies of Republika.co.id and Tempo.co can be explained as follows.

\section{Republika.co.id}

The online version of Republika newspaper (ROL), with its URL Republika.co.id, was first published on 17 August 1995, two years after the print version of the Republika daily newspaper was published. The history of the Republika newspaper originated from the ideas and ideals of the Association of Indonesian Muslim Intellectuals (ICMI), who wanted to disseminate information throughout Indonesia defending the interests of the religion of Islam. The reader segment is focused on the Muslim community. Republika's slogan is 
"educating the life of the nation". This slogan is based on the ideals ICMI to use the mass media to encourage the nation to be critical in the defence of Islamic principles (Fathurokhmah, 2015; Wahid \& Yakut, 2018).

When ROL was launched, it had the tagline, "a window of the people". This means that the majority of Indonesian people are Muslims and view their environment and the outside world using Republika's media as a reference. The window of the people here is also devoted to giving Muslim communities a strong grip on Islamic news and other news.

Republika's vision is "as a trusted media that promotes values that are cool, modern, moderate, Muslim, national, intelligent, and professional has the principle of maintaining the unity and unity of the Indonesian people and Muslims based on the understanding of rahmatan lil alamin (mercy of God for all)". Republika's newspaper often displays da'wah rubrics containing Islamic values and continues to strive to proclaim the history and development of Islam in the archipelago and the world.

\section{Tempo.co}

Initially, the Tempo.co news portal was born with the name Tempo Interaktif (www.tempointeraktif.com). The online portal has developed since 6 March 1996. At the end of 2011, the management agreed to change the name of the Tempo Interaktif portal to Tempo.co. Tempo.co is one of the products owned by the company Tempo Inti Media Tbk. The first edition of Tempo was published on 6 March 1971. In the beginning, it was published weekly. According to Adiba (2016, p. 61), the name Tempo was influenced by the name of a weekly news magazine published in the United States named Time, which was already well known at the time. According to Fathurokhmah (2015), Tempo was conceived as a medium for reform in Indonesia, at which time most mass media were confined to the New Order (Soeharto power) regime. Tempo often voiced press freedom and criticised the New Order government, so that in 1982, Tempo was banned for the first time because it was considered too sharp in criticising the New Order government and its political party, Golkar. However, Tempo was only allowed to reappear after signing an agreement with Ali Moertopo, Minister of Information of the New Order government.

According to Triwardani (2013), Tapsell (2012), Romano (2013), and Hill (2006), the Tempo newspaper during the New Order era followed the principle of investigative journalism, so that it became increasingly sharply criticised by the Soeharto government (New Order). So on 21 June 1994, Tempo was banned the second time by the New Order Minister of Information Harmoko, because it was considered too harsh in its criticism of the government regarding the purchase of used vessels from East Germany.

Tempo.co is present to this day with its vision of being "a reference in increasing public freedom to think and argue and build civilisations that value intelligence and difference". Also, it carries out several missions, including "producing products that are independent and free of all pressures by accommodating and distributing fair and different voices; produce high quality products, and adhere to a code of ethics; become a healthy and prosperous workplace and reflect Indonesia's diversity". 


\section{METHODOLOGY}

This research employed a qualitative research approach by using the framing analysis model introduced by Robert Entman (1993). This study analyzed the news content of Republika.co.id and Tempo.co regarding LGBT news coverage. According to Entman (1993), using framing analysis in analyzing media content may deeply show news direction on certain issues and may explain the meaning behind the presented reality.

According to Kryantono (2006), Eriyanto (2002), with Wahid and Yakut (2018), the strength of the qualitative framing technique is not on the data quantity being analyzed, but on the accuracy of setting the unit of analysis. Based on this opinion, the unit analysis of this research is news about LGBT reported by Republika.co.id and Tempo.co from 9th of February 2016 until 19th February 2016 (refer to Table 1). This unit analysis was chosen based on the consideration that in that period there have been massive news about the LGBT community in Indonesia through the mass media because at that time there was a riot of the sexuality club "Support Group and Resource Center on Sexuality Studies (SGRC)" at the University of Indonesia. At that time, Wahid and Yakut (2018) said that LGBT news became a hot issue and a trending topic in various mass media, including in Republika.co.id and Tempo.co.

This study observed four sets of framing analysis models from Robert Entman (1993), whose stages can be explained below:

- Define Problems - how a media sees an event, and then how to define it. In this context, researchers will see whether the media Republika.co.id and Tempo.co see LGBT from positive or negative aspects.

- Diagnose Causes - what is considered by the media as the cause of a problem. In this context, researchers will see in the media reports Republika.co.id and Tempo.co that LGBT behaviour is something that is reasonable and acceptable in society or LGBT behaviour that is contrary to the values that exist in Indonesian society.

- Make Moral Judgment - what moral values are used by the media to explain problems. In this context, researchers see that the media Republika.co.id and Tempo.co have different moral values. Republika.co.id has Islamic moral values and nationalism. While Tempo.co has a moral value of freedom and diversity. Therefore, the researchers will see that the two media in reporting on LGBT issues that the moral values possessed by each will always be used to legitimize the news.

- Suggest Remedies - solving what the media has to offer to find out the problem. In this case, the researcher looked at the solution provided by Republika.co.id and Tempo.co. Will the two media direct the audience to accept LGBT or not. 


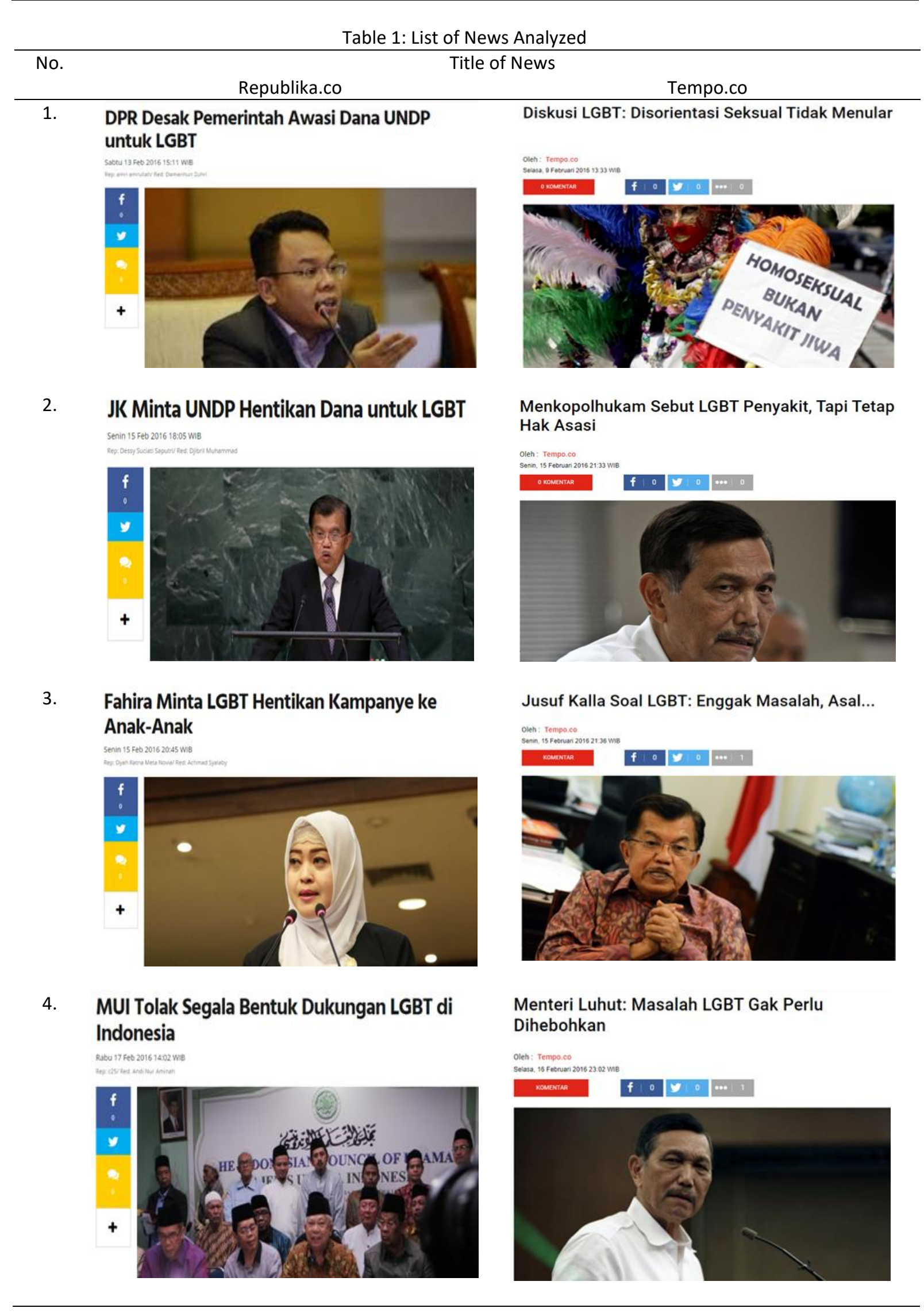




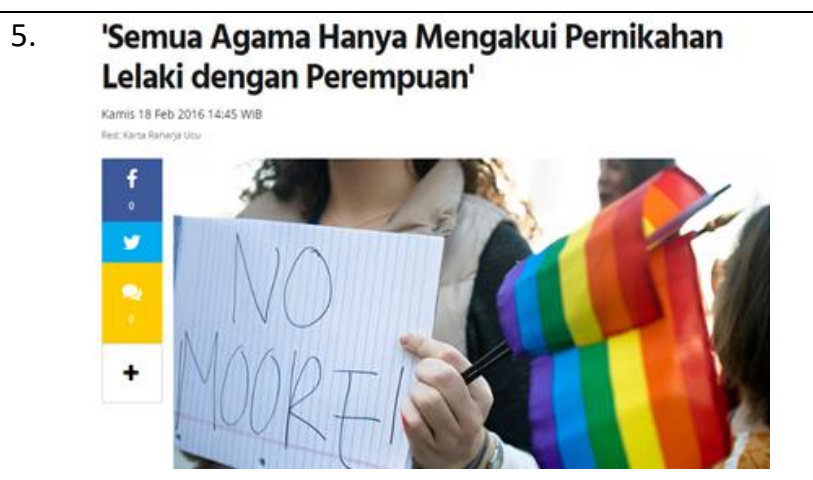

6.
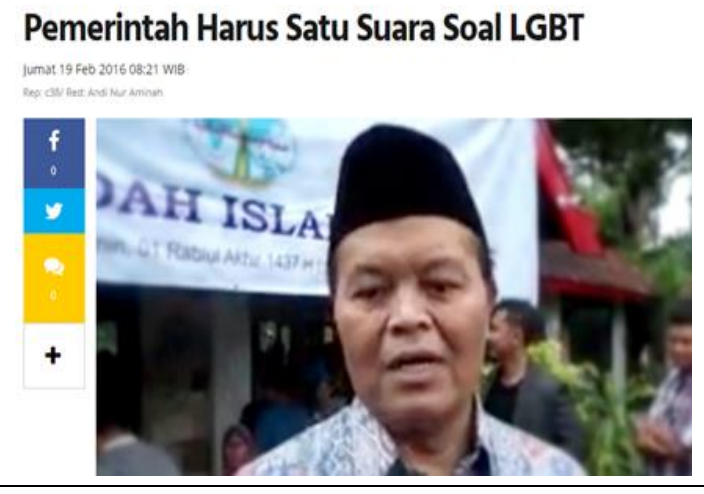

Majelis-majelis Agama Minta Kaum LGBT Dilindungi

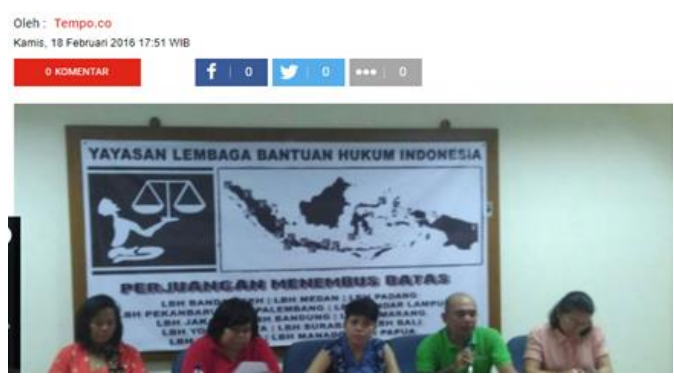

ICMI Minta LGBT Tak Dikucilkan Olen: Tempo.co $201010.10 \mathrm{mun}$
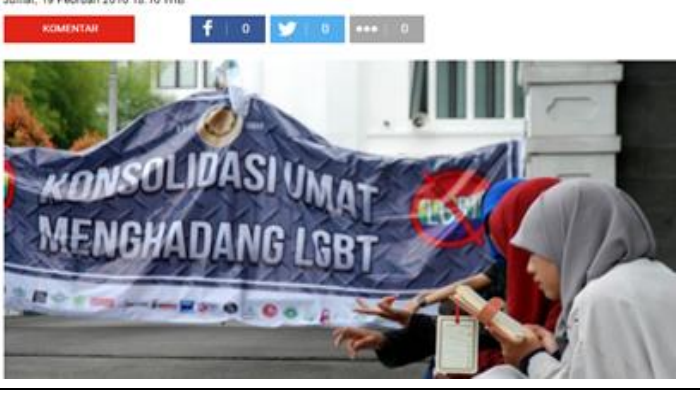

\section{RESULTS AND DISCUSSION}

LGBT on Republika.co.id and Tempo.co News

Stigma against LGBT in Republika.co.id and Tempo.co news was obtained from the analysis of news from 9 February 2016 to 19 February 2016, using four tools of Robert Entman (1993) framing analysis, namely Define Problems, Diagnose Causes, Make Moral Judgement, and Suggest Remedies. The results of the analysis can be summarised as follows.

- Define Problems - Republika.co.id, in its reporting and positioning the Indonesian people in general, does not accept the presence and behaviour of LGBT people. It tends to reject LGBT people in almost all circles, ranging from government, religious leaders, health experts, and academics. LGBT is described as not in accordance with the religious, cultural, and social values prevailing in Indonesia. It can be said that Republika.co.id, through its announcement, considers the issue of LGBT to be an important problem to be resolved so that it does not become a source of problems in the lives of Indonesian people. Tempo.co in its reporting is more supportive and does not question the existence of LGBT in Indonesia. Tempo.co explained that the LGBT issue is not a serious problem for the Indonesian people, because LGBT is a part of the human personality and must be viewed in terms of humanity and human rights. Tempo.co always directs its news so that no parties isolate the LGBT communities. Tempo.co calls on the Indonesian government to find the best way for this LGBT community.

- Diagnose Causes -Republika.co.id sees the source of LGBT in Indonesia as parties who support the existence of this community in Indonesia. In its reporting, Republika.co.id has said that UNDP was an organisation that helped support the existence of LGBT in Indonesia. Republika.co.id reports that there is Rp. 108 billion in funding from UNDP to support LGBT activities in Indonesia. Republika.co.id in its reporting rejects all forms of activity regarding LGBT. It encourages the government to impose sanctions on those 
who are involved with LGBT. Tempo.co, in its reporting, said that the existence of LGBT in Indonesia does not need to be disputed because those involved in the LGBT community are Indonesian citizens and have the same rights as other citizens in the country. The government is asked to provide protection and support for them as citizens. Tempo.co links this problem with the Indonesian Constitution (UUD, 1945) as the legal basis for the Indonesian state to protect this community in Indonesia. Tempo.co stated that the law states that "every citizen has the same position before the law" (Article 27). Therefore, legal protection is the right of all citizens, including the LGBT community. So, Tempo.co stated that LGBT behaviour is the right of every person and part of their human rights so that there is no reason for other parties to ban it.

- Make Moral Judgement - Republika.co.id uses the moral values of Islam to say that LGBT is deviant and something that is forbidden by Islam. Republika.co.id asked the Indonesian government to act decisively and forbid all LGBT activities in Indonesia. It was considered that the funds provided by UNDP to support LGBT activities in Indonesia were wrong. Republika.co.id said that all foreign funds entering Indonesia must go through a process that has been regulated by the laws of the country. So, Republika.co.id thinks that the presence and behaviour of LGBT people will have a negative impact on the younger generations in the country of Indonesia. Meanwhile, Tempo.co, always connects LGBT with human rights. Tempo.co encourages the Indonesian government to provide protection and space to LGBT people because these people are Indonesian citizens who have the same rights under Indonesian law. In addition, Tempo.co stated that the existence of LGBT in Indonesia is not wrong and that what needs to be changed in Indonesian society is not LGBT, but the way the Indonesian people view LGBT people. According to Tempo.co, the characteristics of LGBT have been delivered from birth and that is every person's human right. Everyone must appreciate it.

- Suggest Remedies - Republika.co.id emphasised the settlement of the LGBT presence in Indonesia. It calls for a firm stance by the government to stop the activities of LGBT people in Indonesia. Republika.co.id provides space to give the right to answer this media coverage of the UNDP. They have clarified that no funds have been disbursed to help and support LGBT to develop in Indonesia. Tempo.co is very rare in suggesting a resolution to the existence of LGBT in Indonesia. Tempo.co tends to elevate and emphasise human rights, and link with LGBT activities to get protection from the Indonesian government. Tempo.co seems to be supportive and not too concerned about LGBT activities contrary to social norms in Indonesia. In Islam, only two sexes are recognised, namely male and female. In addition to its definition of gender, the religion of Islam forbids anyone to practice it as committing a serious sin.

\section{Implications of Media Ideology for The Stigma of LGBT}

From the results of this study, it can be said that the difference in reporting about LGBT in the Republika.co.id and Tempo.co media is due to the different ideologies they have. Republika.co.id adheres to Islamic ideology and nationalism, whereas Tempo.co adheres to the ideology of freedom, diversity, and humanity. A study by Akhavan-Majid and Ramaprasad (1998) found that ideological differences would certainly affect the reporting of media. This statement is in accordance with the results of this study related to LGBT on Republika.co.id and Tempo.co. Their research found that Republika.co.id brought a negative 
stigma to LGBT reporting. The principle of Islamic ideology and nationalism as the ideological foundation of Republika.co.id is contrary to the value of universalism. According to Republika.co.id, LGBT values of human rights are universal values of the world, but in some cases, these values are contrary to the values of Indonesian nationalism and Islamic values, as the religion adopted by the majority of Indonesian people. Therefore, Republika.co.id covers more of the negative side of LGBT in Indonesia. Republika.co.id emphasises that LGBT is a large problem in Indonesia that must be resolved immediately. Republika.co.id has often encouraged the government to ban and take action against people involved in the LGBT community. In Tempo.co, LGBT was reported positively. Tempo.co, which is based on the ideology of freedom, diversity, and humanism, is not too concerned about the existence of LGBT in Indonesia. Tempo.co is more prominent on the human rights side, thus encouraging the view that LGBT must retain the same rights under the laws of Indonesia. Tempo.co invites the Indonesian people to accept the LGBT presence in the country. Tempo.co encourages the Indonesian government to provide legal protection regarding their existence.

According to Semykina (2018), the media are seen as a social construction agent that defines reality in the news, so that the media are seen as not a value-free channel. According to Adoni and Mane (1984), Luhmann (2000), that news is not a reflection of actual reality, but it is a reality constructed according to their respective interests. In this regard, Republika.co.id and Tempo.co in the reporting on LGBT issues, has directed the reader's attention to the interests of their respective media ideologies. Republika.co.id's ideology is Islamic and nationalist, and it directs its readers not to accept LGBT by giving certain negative stigma, such as a "community illness". Tempo.co, which has the ideals of freedom, diversity, and humanism, directs the reader through its announcement to accept the existence of LGBT in Indonesia by giving a positive attitude, such as linking LGBT with human rights. Such research can strengthen the opinion expressed by Akhavan-Majid and Ramaprasad (1998), Wahid and Yakut (2018), with Entman (1993), who say that media ideology would have implications for media framing in the news.

The results of this study have supported the research of Wahid and Yakut (2018). The focus of their research is on LGBT media framing on Detik.com and Republika.co.id. They found that Detik.com and Republika.co.id had made news related to LGBT issues based on their respective media ideologies. Detik.com is based on the ideology of humanism. Republika.co.id is Islamic-based, ideological, and nationalistic. This difference in ideology also has implications for LGBT stigma in the news of Detik.com and Republika.co.id. Likewise, with several other studies, including Akhavan-Majid and Ramaprasad (1998), Strand (2012), Johnson (2012), Liebler et al. (2009), Fong et al. (2016), and Engel (2013), they found that the ideology of media had implications for media coverage, including of LGBT issues.

There is a certain stigma against LGBT people in Indonesian society that is inseparable from the role of the media. One function of the mass media is to provide information to the public. But the information provided is very full of meaning (Liebler et al., 2009). The mass media have formed certain images of LGBT people. The mass media have provided images and stereotypes that are attached to LGBT people so that they must accept or reject LGBT people in Indonesia. Each mass medium has its character and background, both in the content and packaging of the news and in its initial appearance and purpose. This difference is motivated by the different interests of each mass medium, those with ideological, political, economic, and religious motives. 
The various interests of the mass media are undeniable. The mass media have political interests because they are funded and supported by certain political forces. The mass media also have economic motives, where material benefits are the only target of the medium. Some are religiously motivated, where mass media are established by certain religious groups to convey their religious values. The existence of these interests also influences the news delivered to the public. Then there is an assumption that the facts conveyed by the mass media are not objective, but facts that have been formed against a particular background of interest. All processes of media formation start by choosing facts, sources, using words, pictures, editing, contributing to how reality is presented to the audience (Entman, 1993; Arandas et al., 2019; Snow, 2004).

In understanding how the media records and constructs a fact, it cannot be separated from how the media captures the reality behind the news. Starting from the search process, the collection and delivery of messages involve news framing agents, who are the journalists and editorial teams, so the news includes their perspectives in interpreting the social reality (Scheufele, 1999; Shoemaker \& Reese, 1996). The media are able to determine which aspects are highlighted or eliminated in accordance with their ideological interests. In this section, a journalist determines the news structure according to their will, from which side an event will be highlighted, and which part of the event takes precedence or is forgotten. Also, the journalist determines which part of the event is highlighted or even eliminated. Finally, the figure who is interviewed becomes a source of news.

\section{CONCLUSION}

When viewing the news presentation by each of these media (Republika.co.id and Tempo.co), it seems that there is a desire by each one to invite the public to know about LGBT issues in accordance with the results of their respective news. If Republika.co.id is based on the ideology of nationalism and Islam, the news emphasises the negative sides. Voices of rejection often appear here. Thus, Republika.co.id desires to invite the public not to accept the existence of LGBT people in this country. Therefore, Republika.co.id's news is more inclined towards the negative side by giving certain stigmas, such as LGBT is considered a disgraceful, deviant, and prohibited act in Islam, so that the audience will reflect the idea that LGBT is something wrong.

In line with the news ideology, most of the actors in Republika.co.id are subjects who are affiliated with Islamic groups. In the concept of media ideology, the group that has the means of production will exercise strong control over the production and circulation of the news to create the meaning of ideas in society. Media owners, as the dominant class, will offer their ideology. Therefore, Republika.co.id dominates ideology in its reporting. Republika.co.id believes that LGBT is a religious, legal, and psychological aberration. They deliberately choose news sources that are affiliated with organisations whose ideology is similar to theirs to control the public space. Meanwhile, the marginal LGBT group does not get significant space in the news, both in the form of news sources and opinion writers in this news source.

Two ideological representations are seen in reporting by Republika.co.id related to LGBT issues. First, the practice of LGBT is considered to originate from the ideology of liberalism. This ideology must be rejected in Indonesia because it is contrary to traditional and religious values. Second, LGBT practices rely on a universal ideology that cannot be fully 
accepted in the Indonesian context because many national norms and regulations are contrary to these universal values. Tempo.co embraces the ideology of freedom, diversity, and humanity. In the news related to LGBT, there seems to be a desire to invite readers to accept this LGBT community in Indonesia. Tempo.co's reporting is more positive by giving readers a positive image of LGBT. Through the news, Tempo.co wants to open up the horizon of thinking of the Indonesian people to see LGBT in terms of human rights. According to Tempo.co, sexual practices are normal human traits and do not need to be criticised. Instead, they must be respected as individual freedom and be worthy of its existence.

In line with its ideology, Tempo.co strives for the principles of freedom, diversity, and universality. Its reporting does not consider the cultural and religious values embraced by the majority of Indonesians, approximately $80 \%$ of whom adheres to Islam (Niko, 2016). And Islam only acknowledges two sexualities, namely male and female. In Indonesian society, the issue of LGBT is still very taboo and sensitive. Indonesian society still emphasises sexuality in nature. However, Tempo.co emphasises the frame of equality. Sexual expression (LGBT) is normal. It should be appreciated by everyone and should not be condemned because it is part of the freedom and life choices of every human being. Tempo.co covers more pro-LGBT voices, especially the voices of human rights activists.

The majority of Indonesian people believe that LGBT issues are contrary to their social norms. But if most Indonesian media provide a large portion of the news on the positive side regarding LGBT issues, this is likely to open up opportunities for Indonesians opposed to LGBT to change their opinion, accepting LGBT in Indonesia. This is in accordance with the opinion of Entman (1993), Bovitz et al. (2002), Terkildsen \& Schnell (1997), Luhmann (2000), Scheufele (1999), Fong et al. (2016), and Arandas et al. (2019), who say that the media will influence public opinion if they give more attention to certain issues and reduce attention to other issues. The audience will know more about something that is given more attention by the media. Then the community will determine the interests of something that follows the arrangement given by the media. For this reason, the role of all elements is needed to maintain the social value of the Indonesian people so that they are not eroded by other cultural values such as LGBT. Including the role of the media is very important to maintain cultural and religious values. Therefore, reporting as already done by Republika.co.id related to LGBT is very important to be carried out by other media in Indonesia so that social and religious values will continue to be maintained in this country.

BIODATA

Hamdani M. Syam is a senior lecturer at Universitas Syiah Kuala, Indonesia. Email: hamdanim.syam@unsyiah.ac.id

Nur Anisah is a senior lecturer at Universitas Syiah Kuala, Indonesia. Email: nuranisah@unsyiah.ac.id

Rahmat Saleh is a senior lecturer at Universitas Syiah Kuala, Indonesia. Email: rahmat_saleh@unsyiah.ac.id

Murti Ali Lingga is an alumni of the communication department at Universitas Syiah Kuala, Indonesia. Email: murtalalingga@gmail.com 


\section{REFERENCES}

Adegbola, O. F. (2019). Points of view and modality in the discourses of homosexuality in selected Nigerian newspapers. International Journal of Linguistics, Literature and Translation, 2(4), 290319. https://publication.ijllt.org/publications/290319/

Adiba, M. A. M. (2016). Kontruksi pemberitaan tentang kelompok radikal State of Iraq and Syria (ISIS) di media Tempo.co dan Republika.co.id. Penerbitan Universitas Sunan Ampel.

Adoni, H., \& Mane, S. (1984). Media and the social construction of reality: Toward an integration of theory and research. Communication Research, 11(3), 323-340. https://doi.org/10.1177/009365084011003001

Akhavan-Majid, R., \& Ramaprasad, J. (1998). Framing and ideology: A comparative analysis of US and Chinese newspaper coverage of the fourth United Nations conference on women an the NGO forum. Mass Communication and Society, 1(3-4), 131-152. https://doi.org/10.1080/15205436.1998.9677853

Arandas, M. F., Kee, C. P., Mohamad, E., \& Idid, S. A. (2019). Framing the first palestinian general elections by Malaysia's New Straits Times. Jurnal Komunikasi: Malaysian Journal of Communication, 35(2), 143-160. https://doi.org/10.17576/JKMJC-2019$\underline{3502-09}$

Atton, C. (2009). Alternative journalism: Ideology and practice. In S. Allan (Ed.), The Routledge companion to news and journalism (pp. 169-178). Routledge.

Bennett, T. (2005). Theories of the media, theories of society. In T. Bennett, J. Curran, M. Gurevitch, \& J. Wollacott (Eds.), Culture, society and the media (pp. 30-55). Routledge.

Bovitz, G. L., Druckman, J. N., \& Lupia, A. (2002). When can a news organization lead public opinion? Ideology versus market forces in decisions to make news. Public Choice, 113(1-2), 127-155.

Bramantyo. (2015, October 12). Airin bantah lakukan tasyakuran pernikahan sejenis. Okezone News. https://news.okezone.com/read/2015/10/12/512/1230637/

Chong, D., \& Druckman, J. N. (2007). Framing theory. Annual Review of Political Science, 10, 103-126.

Cotterrell, R. (1999). Transparency, mass media, ideology and community. Journal for Cultural Research, 3(4), 414-426. https://doi.org/10.1080/14797589909367176

Deuze, M. (2005). What is journalism? Professional identity and ideology of journalists reconsidered. Journalism, 6(4), 442-464. https://doi.org/crxmsf

De Vreese, C. H. (2005). News framing: Theory and typology. Information Design Journal \& Document Design, 13(1), 51-62.

Engel, S. M. (2013). Frame spillover: Media framing and public opinion of a multifaceted LGBT rights agenda. Law \& Social Inquiry, 38(2), 403-441. https://doi.org/f4xaj8

Entman, R. M. (2007). Framing bias: Media in the distribution of power. Journal of Communication, 57(1), 163-173. https://doi.org/10.1111/j.1460-2466.2006.00336.x

Entman, R. M. (1993). Framing: Toward clarification of a fractured paradigm. Journal of Communication, 43(4), 51-58. https://doi.org/10.1111/j.1460-2466.1993.tb01304.x

Eriyanto. (2002). Analisis framing, konstruksi, ideologi dan politik media. LKiS.

Fathurokhmah, F. (2015). Encounter of Islamic ideology radicalism about homosexual discourse in Republika and Tempo Newspaper. Jurnal Penelitian dan Pengembangan Komunikasi dan Informatika, 5(3), 1-9. 
Fong, Y. L., Jeon, S., \& Sulaiman, W. I. W. (2016). Framing of Sewol ferry tragedy: A comparative analysis of South Korean newspapers. Jurnal Komunikasi: Malaysian Journal of Communication, 32(2), 715-748.

Hackett, R. A. (1984). Decline of a paradigm? Bias and objectivity in news media studies. Critical Studies in Media Communication, 1(3), 229-259. https://doi.org/10.1080/15295038409360036

Hamdy, N., \& Gomaa, E. H. (2012). Framing the Egyptian uprising in Arabic language newspapers and social media. Journal of Communication, 62(2), 195-211. https://doi.org/10.1111/j.1460-2466.2012.01637.x

Hassan, I., Azmi, M. N., \& Abubakar, U. I. (2017). Framing Islam in news reporting: A comparative content analysis. Asian Social Science, 13(10), 112-119. https://doi.org/10.5539/ass.v13n10p112

Hill, D. T. (2006). The press in New Order Indonesia. Equinox Publishing.

Iyengar, S., \& Hahn, K. S. (2009). Red media, blue media: Evidence of ideological selectivity in media use. Journal of Communication, 59(1), 19-39. https://doi.org/10.1111/j.1460-2466.2008.01402.x

Johnson, T. (2012). Equality, morality, and the impact of media framing: Explaining opposition to same-sex marriage and civil unions. Politics \& Policy, 40(6), 1053-1080. https://doi.org/10.1111/i.1747-1346.2012.00398.x

Kee, C. P., Ibrahim, F., Ahmad, F., \& Khiang, C. C. (2012). Frame contention between news sources and news media: Framing the dispute of teaching mathematics and science in English. Asian Social Science, 8(5), 16 - 28. http://dx.doi.org/10.5539/ass.v8n5p16

Liebler, C. M., Schwartz, J., \& Harper, T. (2009). Queer tales of morality: The press, same-sex marriage, and hegemonic framing. Journal of Communication, 59(4), 653-675. https://doi.org/10.1111/i.1460-2466.2009.01451.x

Luhmann, N. (2000). The reality of the mass media. Stanford University Press.

Niko, N. (2017). Membedah "Normalisme" dan stigmatisasi gay dalam pemberitaan media di Indonesia. Jurnal Communicate, 1(2), 105-114.

Njoroge, S. M. (2010). Mass media framing of homosexuality: A content analysis of the national daily newspapers in Kenya [Doctoral Dissertation, University of Nairobi, Kenya].

Oliver, P., E., \& Johnston, H. (2005). What a good idea!: Ideologis and frames in social movement research. In H. Johnston, \& J. A. Noakes (Eds.), Frames of protest: Social movements and the framing perspective (pp.185-204). Rowman \& Littlefield Publishers.

Pan, P. L., Meng, J., \& Zhou, S. (2010). Morality or equality? Ideological framing in news coverage of gay marriage legitimization. The Social Science Journal, 47(3), 630-645. https://doi.org/10.1016/i.soscij.2010.02.002

Pasha, S. H. (1993). Towards a cultural theory of political ideology and mass media in the Muslim world. Media, Culture and Society, 15(1), 61-79. https://doi.org/10.1177/016344393015001005

Reese, S. D. (2001). Understanding the global journalist: A hierarchy-of-influences approach. Journalism Studies, 2(2), 173-187. https://doi.org/10.1080/14616700118394

Romano, A. (2013). Politics and the press in Indonesia: Understanding an evolving political culture. London: Routledge.

Scheufele, D. A. (1999). Framing as a theory of media effects. Journal of Communication, 49(1), 103-122. https://doi.org/10.1111/j.1460-2466.1999.tb02784.x 
Scheufele, D. A., \& Tewksbury, D. (2006). Framing, agenda setting, and priming: The evolution of three media effects models. Journal of Communication, 57(1), 9-20. https://doi.org/10.1111/i.1460-2466.2006.00326 5.x

Semykina, K. S. (2018). Media construction of LGBT prides in Russia: Framing dynamics and frame resonance. National Research University Higher School of Economics.

Shoemaker, P. J., \& Reese, S. D. (1996). Mediating the message: Theories of influences on mass media content. Longman.

Shoemaker, P. J., Vos, T. P., \& Reese, S. D. (2009). Journalists as gatekeepers. In K. W. Jorgensen, \& T. Hanitzsch (Eds.), The handbook of journalism studies (pp. 93-107). Routledge.

Snow, D. A. (2004). Framing processes, ideology, and discursive fields. In D. A. Snow, S. A. Soule, \& H. Kriesi (Eds.), The Blackwell companion to social movements (pp. 380412). The Blackwell Publishing.

Snow, D., \& Byrd, S. (2007). Ideology, framing processes, and Islamic terrorist movements. Mobilization: An International Quarterly, 12(2), 119-136.

Strand, C. (2012). Homophobia as a barrier to comprehensive media coverage of the Ugandan anti-homosexual bill. Journal of Homosexuality, 59(4), 564-579. https://doi.org/10.1080/00918369.2012.665679

Tapsell, R. (2012). Politics and the press in Indonesia. Media Asia, 39(2), 109-116. https://doi.org/10.1080/01296612.2012.11689925

Tempo.co. (2015, Oktober 2017). Heboh pernikahan sesama jenis, Warung Darino dibongkar. https://nasional.tempo.co/read/710453/

Terkildsen, N., \& Schnell, F. (1997). How media frames move public opinion: An analysis of the women's movement. Political Research Quarterly, 50(4), 879-900. https://doi.org/10.1177/106591299705000408

Triwardani, R. (2013). Pembreidelan pers di Indonesia dalam perspektif politik media. Jurnal IImu Komunikasi, 7(2), 187-208.

Wahid, U., \& Yakut, S. A. (2018). The framing analysis of news construction on issues lesbian, gay, bisexual, and transgender in online media 'Detik. com and Republika. co. id'. Advanced Science Letters, 24(4), 2387-2391. https://doi.org/10.1166/asl.2018.10960 